\title{
Vanilla bahiana Hoehne (Orchidaceae): studies on fruit development and new perspectives into crop improvement for the Vanilla planifolia group
}

\author{
Tailane Alves do Nascimento ${ }^{1}$, Maura da Silva Costa Furtado ${ }^{2}$, Wanderson Cunha Pereira ${ }^{2}$ \& \\ Felipe Fajardo Villela Antolin Barberena ${ }^{2 *}$ (1) \\ ${ }^{1}$ Universidade Federal da Bahia, Instituto de Biologia, Rua Barão de Jeremoabo, Ondina, Salvador, BA, Brasil \\ ${ }^{2}$ Universidade Federal Rural da Amazônia, Laboratório de Ecologia e Conservação da Amazônia, Estrada do \\ Pau Amarelo, Vila Nova, Capitão Poço, PA, Brasil \\ *Corresponding author: Felipe Fajardo Villela Antolin Barberena, e-mail: felipe.fajardo@ufra.edu.br
}

\begin{abstract}
NASCIMENTO, T.A., FURTADO, M.S.C., PEREIRA, W.C., BARBERENA, F.F.V.A. Vanilla bahiana Hoehne (Orchidaceae): studies on fruit development and new perspectives into crop improvement for the Vanilla planifolia group. Biota Neotropica. 19(3): e20180696. http://dx.doi.org/10.1590/1676-0611-BN-2018-0696
\end{abstract}

\begin{abstract}
Vanilla is the most well-known and economically important genus of Orchidaceae in the world. Vanilla bahiana is restricted to Brazil and its conservation status was recently assessed as 'Endangered'. The species is phylogenetically closely related to $V$. planifolia, whose pods are the main natural source of vanillin. The primary desirable traits for vanilla production are high fruit set and great resistance to abiotic stress. High temperatures $(>$ $32^{\circ} \mathrm{C}$ ) and heavy rain favor fungal infection, and thus are indirectly responsible for fruit drop by $V$. planifolia in cultivation. The aim of the present study was to follow the process of pod ripening of $V$. bahiana in a restinga fragment in an Environmental Protection Area of Bahia State, and to highlight implications for vanilla crop improvement. Fieldwork was carried out from April 2016 to January 2017. A total of nine manual self-pollinations and nine manual cross-pollinations were successfully carried out. Fruit length, diameter and girth were recorded every two weeks. Fruit permanence in the infrutescence was measured as consecutive days from pollination. Descriptive statistics were calculated and Pearson correlation analysis performed among all attributes per pollination method. The influence of temperature and rainfall was also analyzed. Pod measurements and fruit permanence in the infrutescence were higher for cross-pollination than self-pollination. Higher rainfall results in fruit drop. The use of $V$. bahiana in breeding efforts for the genus is here strongly suggested and supported by previously published studies that allowed us to highlight several desirable traits: vanillin production, its wide geographical distribution and occurrence in a variety of habitats; substantial populations; resistance to conditions of drought and high luminosity and temperature; extensive blooming period; high number of flowers per raceme; possible synchronised flowering with V. planifolia, and fruiting throughout the year. These prospects are promising and should be further evaluated, not only for $V$. bahiana but for other vanilla crop wild relatives. Studies of pollination ecology can be used to set guidelines for the conservation of the $V$. planifolia group and to encourage the development of strategies to increase the production of fruit and, consequently, vanillin for its culinary uses and medical applications.
\end{abstract}

Keywords: Bahia State, Brazil, conservation, crop wild relative, vanilla production.

\section{Vanilla bahiana Hoehne (Orchidaceae): estudos sobre o desenvolvimento dos frutos e novas perspectivas para o melhoramento de culturas do grupo Vanilla planifolia}

Resumo: Vanilla é o gênero mais bem conhecido e economicamente importante de Orchidaceae no mundo. A espécie Vanilla bahiana é restrita ao Brasil e seu estado de conservação foi recentemente avaliado como "Em Perigo". A espécie é filogeneticamente próxima de $V$. planifolia, cujos frutos são a principal fonte natural de vanilina. As principais características desejáveis para a produção de baunilha são o elevado número de frutos e grande resistência ao estresse abiótico. Altas temperaturas $\left(>32^{\circ} \mathrm{C}\right)$ e fortes chuvas favorecem a infecção fúngica, sendo, portanto, indiretamente responsáveis pela queda de frutos de $V$. planifolia em cultivo. O objetivo do presente estudo foi acompanhar o processo de maturação do fruto de $V$. bahiana em um fragmento de restinga em uma Área de Proteção Ambiental do estado da Bahia e destacar as implicações para o melhoramento da cultura da baunilha. O trabalho de campo foi realizado de abril de 2016 a janeiro de 2017 . Um total de nove autopolinizações manuais e nove polinizações cruzadas manuais foram realizadas com sucesso. O comprimento, o diâmetro e a circunferência 
dos frutos foram registrados a cada duas semanas. A permanência do fruto na infrutescência foi medida através de dias consecutivos a partir da polinização. Medidas estatísticas descritivas dos atributos morfométricos foram calculadas e a análise de correlação de Pearson foi realizada para verificar a associação entre os pares dos atributos por método de polinização. Também foi analisada a influência da temperatura e da precipitação pluviométrica. As medidas do fruto e a permanência do fruto na infrutescência foram maiores na polinização cruzada do que na autopolinização. $O$ aumento dos índices pluviométricos resulta em queda de frutos. O uso de $V$. bahiana em esforços de melhoramento para o gênero é fortemente sugerido aqui e suportado por estudos publicados anteriormente, que nos permitiram destacar várias características desejáveis: a produção de vanilina; ampla distribuição geográfica e ocorrência em diversos domínios fitogeográficos; formação de populações substanciais; resistência às condições de seca, alta luminosidade e temperatura elevada; extenso período de floração; elevado número de flores por racemo; possível florescimento sincronizado com V. planifolia; e frutificação ao longo do ano. Essas perspectivas são promissoras e devem ser avaliadas não apenas para $V$. bahiana, mas também para outras espécies de Vanilla restritas ao Brasil. Estudos de ecologia de polinização podem ser usados para estabelecer diretrizes para a conservação do grupo V. planifolia e encorajar o desenvolvimento de estratégias para aumentar a produção de frutos e, consequentemente, de vanilina para usos culinários e aplicações médicas.

Palavras-chave: Bahia, Brasil, conservação, parente silvestre de cultivar, produção de baunilha.

\section{Introduction}

Vanilla Mill. is the most well-known and economically important genus of Orchidaceae in the world (e.g. Correll 1953, Ramachandra \& Ravishankar 2000, Lubinsky et al. 2008a). Beans of Vanilla spp., mainly Vanilla planifolia Jacks. ex Andrew, are natural sources of vanillin and vanilla extracts, which are widely used in different cuisines and perfumes (Childers \& Cibes 1948, Bythrow 2005, Havkin-Frenkel $\&$ Belanger 2011). Furthermore, vanillin has been found to be anticarcinogenic, anticlastogenic, antimicrobial and antimutagenic (Bythrow 2005). Important vanilla-producing countries include India, Indonesia, Mexico, Papua New Guinea, Puerto Rico, Uganda, and regions of the Indian Ocean, with less-extensive plantations in several equatorial and tropical countries such as Brazil, Colombia, Costa Rica and Australia (Correll 1953, Sasikumar 2010, Havkin-Frenkel \& Belanger 2011, Osorio et al. 2012). However, Vanilla planifolia has limited genetic variability (Schlüter et al. 2007, Lubinsky et al. 2008a, Minoo et al. 2008), and thus crop wild relatives have been identified as potencial sources of desirable traits for vanilla production, yet field research is needed to better understand their ecology (Nissar et al. 2006, Minoo et al. 2008, Havkin-Frenkel \& Belanger 2011, Gigant et al. 2011, Flanagan et al. 2019).

Vanilla comprises about 120 species, with its highest species richness being in Brazil (37 species, 21 of which are restricted to the country) (Pansarin 2010, Ferreira et al. 2017, Flanagan et al. 2019, Flora do Brasil 2020). The informal $V$. planifolia group encompasses 25 taxa, and includes several American species (Soto Arenas \& Cribb 2010, Barona-Colmenares 2018, Karremans \& Lehamm 2018, Flanagan et al. 2018, 2019). Vanilla bahiana is phylogenetically closely related to Vanilla planifolia and is restricted to Brazil, where it occurs from Maranhão State to São Paulo State. (Bouetard et al. 2010, Gigant et al. 2011, Villanueva-Viramontes et al. 2017, Flora do Brasil 2020). Regarding the conservation status, Vanilla bahiana was recently assessed as 'Endangered' (Ferreira et al. 2017). Vanilla bahiana is a deceptive and self-compatible species. It is pollinator dependent, has short anthesis (few hours) at dawn, and low natural fruit set (ca. 2\%) (Anjos et al. 2017). However, little is known about its fruit development. High temperatures $\left(>32^{\circ} \mathrm{C}\right)$, poor ventilation and heavy rain favor fungal infection, and thus are indirectly responsible for fruit drop by $V$. planifolia in cultivation (Hernández-Hernández 2011). The goals of the present study were to (1) follow the process of pod ripening of $V$. bahiana in a restinga fragment in an Environmental Protection Area of Bahia State, and (2) to highlight implications for vanilla crop improvement.

\section{Material and Methods}

\section{Study area}

The study was carried out in an area of sand dunes in the Área de Proteção Ambiental de Lagoas e Dunas do Abaeté (APA Abaeté) in the municipality of Salvador $\left(12^{\circ} 54^{\prime}-12^{\circ} 57^{\prime} \mathrm{S}, 38^{\circ} 18^{\prime}-38^{\circ} 21^{\prime} \mathrm{W}\right)$, northeastern Brazil (Brasil 2018). This protected area was established in 1987 and covers a total of 1,800 hectares (Bahia 1987). The climate is tropical humid, without a dry season (Köppen 1948), and with relative humidity above $70-80 \%$ throughout the year (Viana \& Kleinert 2005). The annual mean temperature is $25.9{ }^{\circ} \mathrm{C}$, the annual precipitation is $1,885 \mathrm{~mm}$, and April and May are the rainiest months (Schiavone 2014). Distinct restinga phytophysiognomies (sensu Brasil, 2009) are found within APA Abaeté, including herbaceous, shrub and restinga forest formations (Britto et al. 1993, Silva, 2012).

\section{Data collection}

Fruit development of $V$. bahiana was studied during April 2016 and January 2017 (40 weeks) in a restinga forest fragment bordered by a shrub formation (12 $55^{\prime} \mathrm{S}, 38^{\circ} 19^{\prime} \mathrm{W}$ ) and with a discontinuous canopy due to the establishment of trails (Figure 1a). A total of nine manual self-pollinations (SP) and nine manual cross-pollinations (CP) (a single flower per individual) were successfully realized from April 2016 to May 2016. For each raceme, the first flower to open was pollinated (Figure 1b). Pollinations were performed between 08:00 and 08:30 h using all the pollen of the flowers (Anjos et al. 2017). To avoid confusion among treatments, different-colored ribbons were used for each test (Dafni et al. 2005). Fruit lengh (L), diameter (D) and girth (G) was measured every two weeks. Fruit permanence in the infrutescence $(F)$ was measured by counting consecutive days from pollination until the last measurement. 


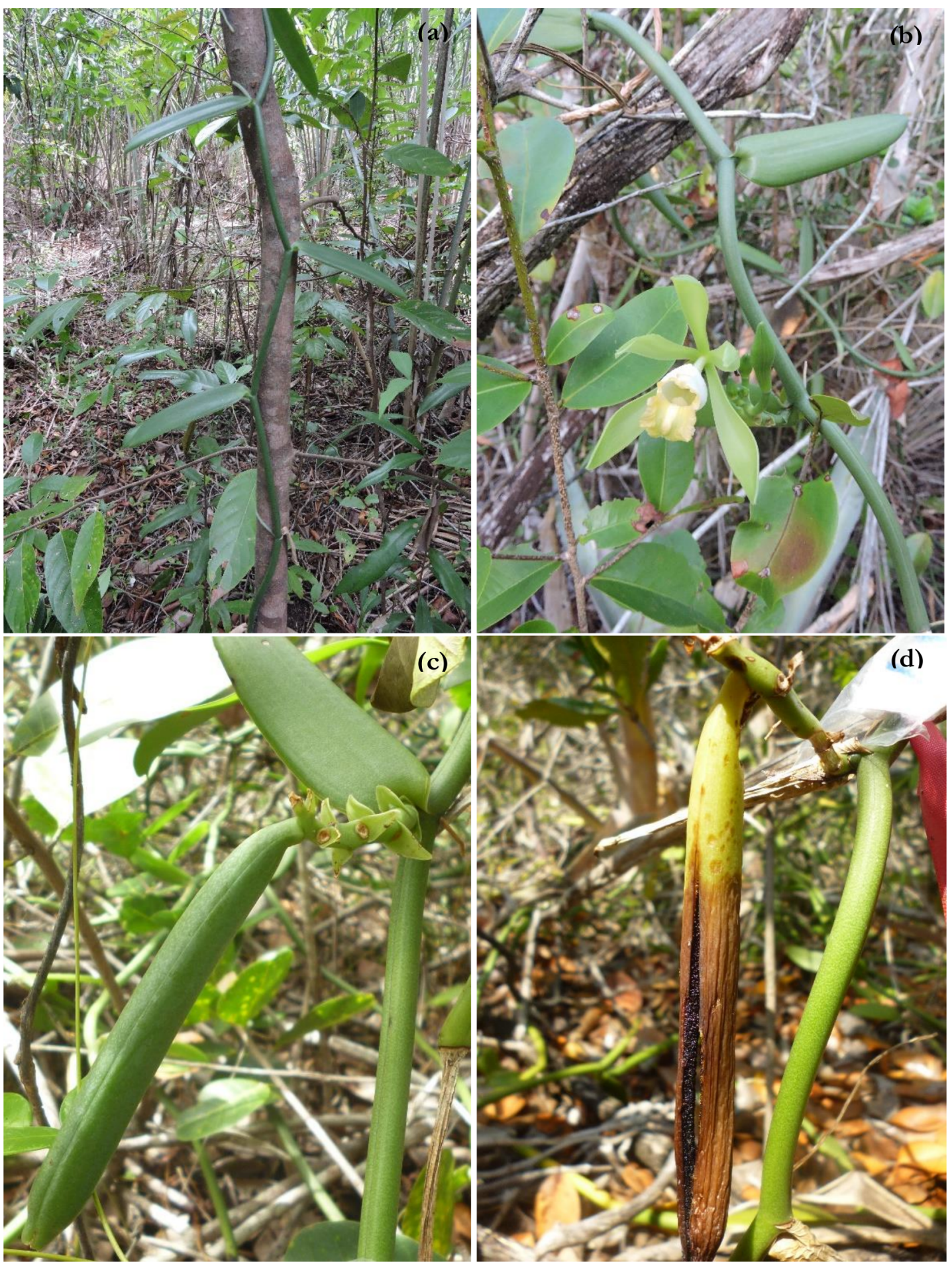

Figure 1. Vanilla bahiana Hoehne. (a) Habitat. (b) Intact flower. For each raceme, the first flower to open was pollinated. (c) Immature fruit formed by manual cross-pollination ( 73 days after pollination; fruit length $=13,2 \mathrm{~cm}$, diameter $=1,1 \mathrm{~cm}$ and girth $=4,0 \mathrm{~cm}$ ). (d) Mature fruit formed by cross-pollination ( 7 months after pollination; fruit length $=13,1 \mathrm{~cm}$, diameter $=1,1$ $\mathrm{cm}$ and girth $=4,5 \mathrm{~cm})$. Photographed by Felipe Fajardo V. A. Barberena $(\mathrm{a}, \mathrm{b})$ and Tailane Alves do Nascimento (c, d).

\section{Data analysis}

Descriptive statistics, including means, medians, standard deviations, skewness and kurtosis were calculated for the four parameters in order to verify numerically the behavior of the data. Pearson's correlation analysis was used to test the association between pairs of attributes (Callegari-Jacques 2003), and the level of significance for each pair was calculated by Test T. An exploratory analysis of the data was also carried out. Coefficients of variation $(\mathrm{CV})$ for the variables were compared in order to verify the homogeneity of the data around the mean (Pimentel-Gomes 2009). We adopted the following classification for the coefficients of variation (Pimentel-Gomes 2009): low (<10\%), 
medium (10-20\%), high (20-30\%), and very high (>30\%). Correlations between all the previously mentioned attributes and temperature (T) and rainfall (R) were also analyzed. Compiled data for temperature and rainfall were obtained from Instituto Nacional de Meteorologia (2018) for the study period. Additional data on reproductive biology of $V$. bahiana, encompasing two flowering seasons (2014/2015 and 2015/2016), were extracted from Anjos et al. (2017).

\section{Results}

Fruit maturation is visually evidenced by yellowing and dehiscence of the fruit apex and often occurs about seven months after pollination (up to 217 days after pollination, data not presented) (Figure 1c, d). Regarding the mean of the data, beans formed by manual self-pollination had smaller measurements for length $(8.26 v s 9.09 \mathrm{~cm})$, girth $(2.84 v s$. $3.12 \mathrm{~cm})$ and diameter $(0.84 v s 0.87 \mathrm{~cm})$ than fruits formed by manual cross-pollination; coefficients of variation of the three attributes were higher for manual cross-pollination, reflecting the higher means (Table 1 and 2). Similarly, fruit permanence in the infrutescence was longer for cross-pollination than manual-pollination. From the coefficient of variation, a comparison statistic that measures the dispersion of the data around the mean, it was verified that the variation of $F$ was very high for both pollination methods, showing a high degree of variability of the data, which is associated with long permanence. The coefficients of variation for the attributes L, D and C were medium or high for the two pollination methods. These data show that some fruits have more developed morphometric characteristics. Tables 1 and 2 show the descriptive statistics for the attributes according to pollination method.

In self-pollination, fruit length was directly proportional to fruit diameter, girth and permanence, but inversely proportional to rainfall. Girth was directly proportional to fruit diameter and permanence, but inversely proportional to rainfall. Fruit permanence and rainfall were inversely proportional. No statistically significant correlations were recorded between temperature and the morphometric attributes. (Table 3).

In cross-pollination, fruit length was directly proportional to fruit diameter, girth and permanence, but inversely proportional to rainfall. Similarly, fruit diameter was directly related to girth and permanence, and inversely related to rainfall. A significant direct relationship between permanence and girth, and inverse relationships between rainfall and girth and between rainfall and permanence were also recorded. No statistically significant correlations were observed between temperature and the morphometric attributes. (Table 4).

\section{Discussion}

Ripening of the fruits of Vanilla is essential for obtaining greater amounts of vanillin, and the first month of pod development is a critical phase for Vanilla planifolia bean growth (Nissar et al. 2006). For both pollination methods studied longer permanence of the fruit of Vanilla bahiana in the infrutescence contributes to increases in all the morphometric attributes studied (except for diameter in manual pollination, for which no correlation was recorded). Plants of restinga experience several limiting conditions such as low water retention and intense sunlight (Rizzini 1997). Although the mean monthly maximum temperature exceeded $32^{\circ} \mathrm{C}$ only in January 2017 (Instituto Nacional de Meteorologia 2018), the soil temperature in restinga is much higher, reaching about $50^{\circ} \mathrm{C}$. Nonetheless, individuals of $V$. bahiana occur in shade in the study area and fruit drop does not seem to be correlated with high temperatures. However, higher rainfall was responsible for a significant decrease in the development of fruit length, girth and time of permanence in the infrutescence (fruit drop tends to occur at the beginning of development). Thus, cultivation of $V$. bahiana inside greenhouses can be a strategy to decrease fruit drop, since

Table 1. Descriptive statistics for morphometric attributes and time of permanence for fruit formed by manual self-pollination of Vanilla bahiana Hoehne at Área de Proteção Ambiental das Lagoas e Dunas do Abaeté. Attribute: $\mathrm{D}=$ diameter; $\mathrm{F}=$ time of permanence of the fruit in the infrutescence; $\mathrm{G}=$ girth; $\mathrm{L}=$ length.

\begin{tabular}{|c|c|c|c|c|c|c|c|c|}
\hline \multicolumn{9}{|c|}{ Descriptive statistical measures } \\
\hline \multirow{2}{*}{ Attribute } & \multirow{2}{*}{ Mean } & \multirow{2}{*}{ Median } & \multicolumn{2}{|c|}{ Value } & \multirow{2}{*}{$\begin{array}{l}\text { Standard } \\
\text { Deviation }\end{array}$} & \multicolumn{3}{|c|}{ Coefficient } \\
\hline & & & Minimum & Maximum & & CV(\%) & Kurtosis & Skewness \\
\hline $\mathrm{F}$ & 71.22 & 40.00 & 21.00 & 212.00 & 74.13 & $104.1 \%$ & 0.83 & 1.60 \\
\hline G & 2.84 & 2.70 & 2.17 & 4.10 & 0.59 & $20.8 \%$ & 1.85 & 1.29 \\
\hline
\end{tabular}

Table 2. Descriptive statistics for morphometric attributes and time of permanence for fruit formed by manual cross-pollination of Vanilla bahiana Hoehne at Área de Proteção Ambiental das Lagoas e Dunas do Abaeté. Attribute: $\mathrm{D}=$ diameter; $\mathrm{F}=$ time of permanence of the fruit in the infrutescence; $\mathrm{G}=$ girth; $\mathrm{L}=$ length.

\begin{tabular}{|c|c|c|c|c|c|c|c|c|}
\hline \multicolumn{9}{|c|}{ Descriptive statistical measures } \\
\hline \multirow{2}{*}{ Attribute } & \multirow{2}{*}{ Mean } & \multirow{2}{*}{ Median } & \multicolumn{2}{|c|}{ Value } & \multirow{2}{*}{$\begin{array}{l}\text { Standard } \\
\text { Deviation }\end{array}$} & \multicolumn{3}{|c|}{ Coefficient } \\
\hline & & & Minimum & Maximum & & CV(\%) & Kurtosis & Skewness \\
\hline $\mathrm{F}$ & 114.22 & 48.00 & 35.00 & 213.00 & 89.59 & $78.44 \%$ & -2.55 & 0.27 \\
\hline G & 3.12 & 2.86 & 2.48 & 3.81 & 0.55 & $17.63 \%$ & -2.07 & 0.21 \\
\hline
\end{tabular}


Table 3. Pearson correlation coefficients for environmental variables and morphometric attributes of the fruit of Vanilla bahiana Hoehne formed by manual selfpollination at Área de Proteção Ambiental das Lagoas e Dunas. Attribute: $\mathrm{D}=$ diameter; $\mathrm{F}=$ time of permanence of the fruit in the infrutescence; $\mathrm{G}=$ girth; $\mathrm{L}=$ length; $\mathrm{R}=$ rainfall; $\mathrm{T}=$ temperature. ${ }^{* *}$ Significant at 0.01 probability $(\mathrm{p}<0.01)$ by the T-Test. * Significant at 0.05 probability $(\mathrm{p}<0.05)$ by the T-Test. NS, not significant $(\mathrm{p}>0.05)$ by the T-Test.

\begin{tabular}{|c|c|c|c|c|c|c|}
\hline \multirow{2}{*}{ Attribute } & \multicolumn{6}{|c|}{ Correlation Coefficient } \\
\hline & D & $\mathbf{F}$ & G & $\mathbf{L}$ & $\mathbf{R}$ & $\mathbf{T}$ \\
\hline $\mathrm{D}$ & 1 & & & & & \\
\hline $\mathrm{G}$ & $0.861 * *$ & $0.863^{* *}$ & 1 & & & \\
\hline $\mathrm{L}$ & $0.765^{*}$ & $0.938 * *$ & $0.970 * *$ & 1 & & \\
\hline
\end{tabular}

Table 4. Pearson correlation coefficients for environmental variables and morphometric attributes of the fruit of Vanilla bahiana Hoehne formed by manual cross-pollination at Área de Proteção Ambiental das Lagoas e Dunas. Attribute: $\mathrm{D}=$ diameter; $\mathrm{F}=$ time of permanence of the fruit in the infrutescence; $\mathrm{G}=$ girth; $\mathrm{L}=$ Lengh; $\mathrm{R}=$ rainfall; $\mathrm{T}=$ temperature. $* *$ Significant at 0.01 probability $(\mathrm{p}<0.01)$ by the T-Test. * Significant at 0.05 probability $(\mathrm{p}<0.05)$ by the T-Test. NS, not significant $(\mathrm{p}>0.05)$ by the T-Test.

\begin{tabular}{cccccc}
\hline \multirow{2}{*}{ Attribute } & \multicolumn{5}{c}{ Correlation Coefficient } \\
\cline { 2 - 6 } & $\mathbf{D}$ & $\mathbf{F}$ & $\mathbf{G}$ & $\mathbf{L}$ & $\mathbf{R}$ \\
\hline $\mathrm{D}$ & 1 & & & \\
$\mathrm{~F}$ & $0.964^{* *}$ & 1 & & & \\
$\mathrm{G}$ & $0.970^{* *}$ & $0.955^{* *}$ & 1 & & \\
$\mathrm{~L}$ & $0.886^{* *}$ & $0.921^{* *}$ & $0.920^{* *}$ & 1 & 1 \\
$\mathrm{R}$ & $-0.865^{* *}$ & $-0.829^{* *}$ & $-0.858^{* *}$ & $-0.703^{*}$ & $-0.080^{\mathrm{NS}}$ \\
$\mathrm{T}$ & $-0.522^{\mathrm{NS}}$ & $-0.621^{\mathrm{NS}}$ & $-0.504^{\mathrm{NS}}$ & $-0.653^{\mathrm{NS}}$ & 1 \\
\hline
\end{tabular}

the shading can be administered and the amount of water regulated, benefiting fruit production. In addition, cross-pollination is preferred over self-pollination because of the longer permanence of the fruit in the infrutescence, which also benefits fruit production (see levels of correlation between the variables; Tables 3 and 4).

The formation of natural and artificial hybrids is recurrent in the genus Vanilla, and has included taxa native to different continents (Nielsen 2000, Nissar et al. 2006, Minoo et al. 2008, Soto Arenas \& Dressler 2010). Hybridization has been exploited to obtain genetic variability and vanilla crop improvement, but is still at an early stage of development (Nissar et al. 2006, Lubinsky et al. 2008b, Sasikumar 2010). The primary desirable traits for vanilla production are high flower production and fruit set, and great resistance to disease and abiotic stress (Soto Arenas 1999). Breeding programs have proven to be efficient, but remain mostly based on species distantly related to $V$. planifolia, when they should involve American species (Soto Arenas \& Dressler 2010, Cameron 2011).

Vanilla bahiana presents promising traits that are of value in vanilla crop improvement and may be a good initial choice for new breeding efforts with $V$. planifolia. The species has recently been found to produce significant amounts of vanillin and other compounds related to vanilla flavor (Lopes 2018). In addition, there are other determinant factors to consider: Vanilla bahiana has (1) a wide geographical distribution (Ferreira et al. 2017, Flora do Brasil 2020); (2) occurs in different vegetation types and phytogeographic domains - Caatinga and Cerrado, as well as the Atlantic Forest; (3) forms substantial populations in restinga fragments (at least 160 individuals in the study area) - whereas natural populations of several species of Vanilla are small (Soto Arenas 1999); (4) is resistant to conditions of drought and high luminosity and temperature; (5) has a long blooming period (over an eight-month period in restinga areas) (Anjos et al. 2017); (6) produces a high number of flowers per raceme - Vanilla bahiana bears more flowers than several Vanilla species, including V. planifolia (up to 31 flowers per inflorescence versus 24 flowers) (Childers \& Cibes 1948, Anjos et al., 2017); (7) has possible synchronized flowering with $V$. planifolia due to partial overlap of anthesis and pollination times (Soto Arenas 1999, Nissar et al. 2006); and (8) fruits throughout the year (Anjos et al. 2017). Therefore, it may be possible to have flowers, and consequently fruits, throughout the year and over a long period of time (months) for performing vanilla pollination. Furthermore, the adaptations possessed by $V$. bahiana to adverse abiotic factors may favor cropping in areas that are drier and have higher-luminosity, conditions that also reduce the propensity for disease.

These results and prospects are promising and should be further evaluated, not only for $V$. bahiana but for other vanilla crop wild relatives. Experiments with wild species as part of vanilla breeding programs is recommended for growing areas, mainly in tropical and equatorial regions where the most significant plantings are concentrated. Concomitantly, investigation into the reproductive biology of other Brazilian species of Vanilla should continue, since studies of pollination ecology can be used to set guidelines for the conservation of the $V$. planifolia group and to encourage the development of strategies to increase the production of fruit and, consequently, vanillin for its culinary uses and medical applications. 
Finally, it is necessary to plan appropriate management of genetic resources, including not only the possible reformulation and expansion of vanilla crops, but also in situ conservation efforts for the species. Habitat fragmentation is a concern in areas near APA Lagoas e Dunas do Abaeté, as it is in innumerable unprotected areas of Brazil, and may result in rapid population declines of species of Vanilla. It is particularily worrying for species threatened with extinction, such as Vanilla bahiana and Vanilla dubia Hoehne (Menini Neto et al. 2013, Ferreira et al. 2017). The conservation status of the other species of $V$. planifolia group that occur in the country has not been assessed for red lists. Therefore, proper assessment of the conservation status of these species is a necessary next step towards the conservation of the gene pool of Vanilla. Ex situ conservation actions are also extremely important, and will facilitate research of potential agronomic traits, as well as crop breeding (Flanagan \& Mosquera-Espinosa 2016, Flanagan et al. 2019).

\section{Acknowledgements}

We are grateful to Jorge Santana for granting permission for the fieldwork, and to Erik Russell Wild for the English-language review. FFVAB thanks Fundação de Amparo à Pesquisa do Estado da Bahia (FAPESB) for financial suport to the project "Estudos florísticos, taxonômicos e ecológicos em Orchidaceae em remanescentes florestais e de restinga na região metropolitana de Salvador, Bahia, Brasil" (DCR0028/2015). FFVAB and TAN thank Conselho Nacional de Desenvolvimento Científico e Tecnológico (CNPq) (313237/2015-8) and Universidade Federal da Bahia for the fellowship grants.

\section{Author Contributions}

Tailane Alves do Nascimento: Substantial contribution in the concept and design of the study; contribution to data collection; contribution to manuscript preparation.

Maura da Silva Costa Furtado: Contribution to data analysis and interpretation; contribution to manuscript preparation.

Wanderson Cunha Pereira: Contribution to data analysis and interpretation; and contribution to manuscript preparation.

Felipe Fajardo Villela Antolin Barberena: Substantial contribution in the concept and design of the study; contribution to manuscript preparation; contribution to critical revision, adding intelectual content.

\section{Conflicts of interest}

The authors declare that they have no conflict of interest related to the publication of this manuscript.

\section{References}

ANJOS, A.M., BARBERENA, F.F.V.A. \& PIGOZZO, C.M. 2017. Biologia reprodutiva de Vanilla bahiana Hoehne (Orchidaceae). Orquidário 30 (3/4): 67-79.

BAHIA. Diário Oficial do Estado da Bahia. Decreto n ${ }^{\circ} 351$, de 22 de setembro de 1987. 1987. http://www.icmbio.gov.br/cepsul/images/stories/legislacao/ Decretos/1987/dec ba 3511987 uc criaapa lagoas dunasabaete salvador ba altrd $\overline{\operatorname{dec}} 254 \overline{0} 199 \overline{3}$ res cepram $302 \overline{3}$ 2002.pdf/. (último acesso em 29/04/2018)
BARONA-COLMENARES, A.A. 2018. Two new records in Orchidaceae (Vanillinae) from southernmost Colombian Amazonia: Vanilla javieri, a new species, and Vanilla appendiculata. Phytotaxa 375 (4): 261-273. DOI:10.11646/phytotaxa.375.4.2

BOUETARD, A., LEFEUVRE, P., GIGANT, R., BORY, S., PIGNAL, M., BESSE, P. \& GRISONI, M. 2010. Evidence of transoceanic dispersion of the genus Vanilla based on plastid DNA. Molecular Phylogenetics and Evoution 55: 621-630. DOI:10.1016/j.ympev.2010.01.021

BRASIL. Ministério do Meio Ambiente. Resolução Conama no 417, de 23 de novembro de 2009. 2009. http://www.mma.gov.br/port/conama/legiabre. cfm?codlegi=617/. (último acesso em 29/04/2018).

BRASIL. Ministério do Meio Ambiente. Download de dados geográficos. 2018. http://mapas.mma.gov.br/i3geo/datadownload.htm/. (último acesso em 29/04/2018)

BRITTO, I.C., QUEIROZ, L.P., GUEDES, M.L.S., OLIVEIRA, N.C. \& SILVA, L.B. 1993. Flora Fanerogâmica das Dunas e Lagoas do Abaeté, Salvador, Bahia. Sitientibus Série Ciências Biológicas 11: 31-46.

BYTHROW, J.D. 2005. Vanilla as a medicinal plant. Seminars in Integrative Medicine 3: 129-131. DOI:10.1016/j.sigm.2006.03.001

CALLEGARI-JACQUES, S.M. 2003. Bioestatística: princípios e aplicações. 1 ed. Artemed, Porto Alegre.

CAMERON, K.M. 2011. Vanilla phylogeny and classification. In Handbook of Vanilla science and technology (D. Havkin-Frenkel \& F.C. Belanger, eds). Wiley-Blackwell, Chichester, p. 243-255

CHILDERS, N.F. \& CIBES H.R. 1948. Vanilla culture in Puerto Rico. Federal experiment station in Puerto Rico. Circular n ${ }^{\circ} 28$. United States Department of Agriculture, Mayaguez.

CORRELL, D.S. 1953. Vanilla - Its botany, history, cultivation and economic import. Economic Botany 7: 291-358.

DAFNI, A., KEVAN, P.G. \& HUSBAND, B.C. 2005. Practical pollination biology. 1 ed. Enviroquest, Cambridge.

FERREIRA, A.W.C., OLIVEIRA, M.S., SILVA, E.O., CAMPOS, D.S., PANSARIN, E.R. \& GUARÇONI, E.A.E. 2017. Vanilla bahiana Hoehne and Vanilla pompona Schiede (Orchidaceae, Vanilloideae): two new records from Maranhão state, Brazil. CheckList 13 (6): 1131-1137.

FLANAGAN, N.S. \& MOSQUERA-ESPINOSA, A.T. 2016. An integrated strategy for the conservation and sustainable use of native Vanilla species in Colombia. Lankesteriana 16 (2): 201-218. DOI:10.15517/lank.v16i2.26007

FLANAGAN, N.S., OSPINA-CALDERÓN, N.H., AGAPITO, L.T.G., MENDOZA, M. \& MATEUS, H.A. 2018. A new species of Vanilla (Orchidaceae) from the North West Amazon in Colombia. Phytotaxa 364 (3): 250-258. DOI: 10.11646/phytotaxa.364.3.4

FLANAGAN, N.S., CHAVARRIAGA, P. \& MOSQUERA-ESPINOSA, A.T. 2019. Conservation and sustainable use of Vanilla crop wild relatives in Colombia. In Handbook of Vanilla science and technology. 2 ed. (D. HavkinFrenkel \& F.C. Belanger, eds). Wiley-Blackwell, Chichester, p. 85-110.

FLORA DO BRASIL. Jardim Botânico do Rio de Janeiro. 2020. http:// floradobrasil.jbrj.gov.br/reflora/floradobrasil/FB179/. (último acesso em 29/04/2018).

GIGANT, R., BORY, S., GRISONI, M. \& BESSE, P. 2011. Biodiversity and evolution in the Vanilla genus. In The dynamical processes of biodiversity - case studies of evolution and spatial distribution (O. Grillo \& G. Venora, eds). Intech, Rijeka, p. 1-26.

HAVKIN-FRENKEL, D. \& BELANGER, F.C. 2011. Handbook of Vanilla Science and Technology. 1 ed. Wiley-Blackwell, Chichester.

HERNÁNDEZ-HERNÁNDEZ, J. 2011. Mexican Vanilla production. In Handbook of Vanilla science and technology. 1 ed. (D. Havkin-Frenkel \& F.C. Belanger, eds). Wiley-Blackwell, Chichester, p. 3-25.

INSTITUTO NACIONAL DE METEOROLOGIA. Boletim agroclimatológico mensal. 2018. http://www.inmet.gov.br/portal/index. php?r=agrometeorologia/boletinsAgroclimatologicos/. (último acesso em $16 / 04 / 2018)$. 
KARREMANS, A.P. \& LEHMANN, P. 2018. A highly threatened new species of Vanilla from Costa Rica. Lindleyana 87 (4): 304-307.

KÖPPEN, W. 1948. Climatologia: com um estúdio de los climas de la tierra. 1 ed. Fondo de Cultura Económica, México.

LOPES, E.M. 2018. Vanilla bahiana, fonte alternativa da Mata Atlântica para a produção de baunilha: uma abordagem proteômica através de nanoLC-MS de alta definição. MSc Thesis, Universidade Federal do Estado do Rio de Janeiro, Rio de Janeiro.

LUBINSKY, P., BORY, S., HERNÁNDEZ, J.H., KIM, S-C. \& GÓMEZ-POMPA, A. 2008a. Origins and dispersal of cultivated vanilla (Vanilla planifolia Jacks. [Orchidaceae]). Economic Botany 62: 127-138.

LUBINSKY, P., CAMERON, K.M., MOLINA, M.C., WONG, M., LEPERSANDRZEJEWSKI, S., GÓMEZ-POMPA, A. \& KIM, S-C. 2008b. Neotropical roots of a polynesian spice: the hybrid origin of Tahitian vanilla, Vanilla tahitensis (Orchidaceae). American Journal of Botany 95: 1040-1047. DOI:10.3732/ajb.0800067

MENINI NETO, L., BARROS, F., VINHOS, F., FURTADO, S.G., JUDICE, D.M., FERNANDEZ, E.P., SFAIR, J.C., BARROS, F.S.M., PRIETO, P.V., KUTSCHENKO, D.C., MORAES, M.A., ZANATA, M.R.V. \& SANTOS FILHO, L.A.F. 2013. Orchidaceae. In Livro Vermelho da Flora do Brasil (G. Martinelli \& M. A. Moraes, eds.). Centro Nacional de Conservação da Flora, Rio de Janeiro, p. 749-818.

MINOO, D., JAYAKUMAR, V.N., VEENA, S.S., VIMALA, J., BASHA, A., SAJI, K.V., NIRMAL BABU, K. \& PETER, K.V. 2008. Genetic variations and interrelationships in Vanilla planifolia and few related species as expressed by RAPD polymorphism. Genetic Resources and Crop Evolution 55: 459-470. DOI 10.1007/s10722-007-9252-3

NIELSEN, L.R. 2000. Natural hybridization between Vanilla claviculata (W.Wright) Sw. and V. barbellata Rchb.f. (Orchidaceae): genetic, morphological, and pollination experimental data. Botanical Journal of the Linnean Society 133: 285-302.

NISSAR, V.A.M., HRIDEEK, T.K., KURUVILLA, K.M., MADHUSOODANAN, K.J. \& THOMAS, J. 2006. Studies on pollination, inter specific hybridization and fruit development in vanilla. Journal of Plant Crops 34: 167-170.

OSORIO, A.I., OSORIO, N.W., DIEZ, M.C., MORENO, F.H. 2012. Effect of organic substrate composition, fertilizer dose, and microbial inoculation on vanilla plant nutrient uptake and growth. Acta Horticulturae 964: 135-142.
PANSARIN, E.R. 2010. Vanilla dietschiana, returns from Dictyophyllaria. Orchids (West Palm Beach) 79: 106-109.

PIMENTEL-GOMES, F. 2009. Curso de Estatística Experimental. 1 ed. Fundação de Estudos Agrários Luiz de Queiroz, Piracicaba.

RAMACHANDRA RAO, S. \& RAVISHANKAR, G.A. 2000. Vanilla flavour: production by conventional and biotechnological routes. Journal of the Science of Food and Agriculture 80: 289-304.

RIZZINI, C.T. 1997. Tratado de fitogeografia do Brasil. Aspectos ecológicos, sociológicos e florísticos. 2 ed. Âmbito Cultural Edições Ltda, Rio de Janeiro.

SASIKUMAR, B. 2010. Vanilla breeding: a review. Agricultural Research Communication Centre 31: 139-144.

SCHIAVONE, D.C. 2014. Macroinvertebrados bentônicos como indicadores da integridade de ecossistemas de água doce costeiros. Estudo de caso: lagos do Parque das Dunas, Salvador, BA. MSc Thesis, Universidade de São Paulo, São Carlos.

SCHLÜTER, P.M., ARENAS, M.A.S. \& HARRIS, S.A. 2007. Genetic variation in Vanilla planifolia (Orchidaceae). Economic botany 61 (4): 328-336.

SILVA, F.O. 2012. Biodiversidade e interações positivas em moitas de restinga. PhD Thesis, Universidade Federal da Bahia, Salvador.

SOTO ARENAS, M.A. 1999. Filogeografía y recursos genéticos de las vanillas de México. Informe final SNIB-CONABIO proyecto No. J101. Instituto Chinoin AC., Yucatán.

SOTO ARENAS, M.A. \& CRIBB, P. 2010. A new infrageneric classification and synopsis of the genus Vanilla Plum. ex Mill. (Orchidaceae: Vanillinae). Lankesteriana 9: 355-398.

SOTO ARENAS, M.A. \& DRESSLER, R.L. 2010. A revision of the mexican and central american species of Vanilla Plumier ex Miller with a characterization of their ITS region of the nuclear ribosomal DNA. Lankesteriana 9: 285-354.

VIANA, B.F. \& KLEINERT, A.M.P. 2005. A community of flower-visiting bees (Hymenoptera: Apoidea) in the coastal sand dunes of Northeastern Brazil. Biota Neotropica 5(2): 1-13. DOI: 10.1590/S1676-06032005000300005

VILLANUEVA-VIRAMONTES, S., HERNÁNDEZ-APOLINAR, M., FERNÁNDEZ-CONCHA, G.C., DORANTES-EUÁN, A., DZIB, G.R. \& MARTÍNEZ-CASTILLO, J. 2017. Wild Vanilla planifolia and its relatives in the MexicanYucatan Peninsula: Systematic analyses with ISSR and ITS. Botanical Sciences 95: 169-187. DOI: 10.17129/botsci.668. 